\title{
Micro-level Estimation of Methionine Using Inhibitory Kinetic Spectrophotometric Method
}

\author{
Abhishek Srivastava 1,* (1) \\ 1 Department of Chemistry, GLA University, Mathura, U.P., India \\ * Correspondence: aabhichem@gla.ac.in;
}

Received: 1.10.2020; Revised: 3.11.2020; Accepted: 5.11.2020; Published: 7.11.2020

\begin{abstract}
A large number of bioactive molecules and drugs contain sulfur as an important constituent. Organo-sulfur compounds form a stable complex with $\mathrm{Hg}^{2+}$ thereby inhibiting its catalytic activity. The $\mathrm{Hg}^{2+}$ catalyzed the exchange rate of cyanide with nitroso-R-salt $[\mathrm{N}-\mathrm{R}$-salt $]$ from $\left[\mathrm{Ru}(\mathrm{CN})_{6}\right]^{4-}$ will be reduced by the addition of sulfur-containing amino acid, methionine (MET). This inhibitory property of MET can be employed for its micro-level kinetic determination. Optimum reaction condition viz. $\mathrm{I}=0.05 \mathrm{M}\left(\mathrm{KNO}_{3}\right), \mathrm{pH}=7.0 \pm 0.02,\left[\mathrm{Ru}(\mathrm{CN})_{6}{ }^{4}\right]=5.25 \times 10^{-5} \mathrm{M},[\mathrm{N}-\mathrm{R}$-salt $]=6.5 \times 10^{-4} \mathrm{M},\left[\mathrm{Hg}^{+2}\right]=$ $5.5 \times 10^{-5} \mathrm{M}$, and Temperature $=45.0 \pm 0.1{ }^{\circ} \mathrm{C}$ were utilized to investigate the kinetic measurements at $525 \mathrm{~nm}\left(\lambda_{\max }\right.$ of $\left[\mathrm{Ru}(\mathrm{CN})_{5} \mathrm{~N}-\mathrm{R} \text {-salt }\right]^{3-}$ complex $)$. To explain the mechanism of inhibition caused by methionine on $\mathrm{Hg}^{2+}$ catalyzed exchange of cyanide with $\mathrm{N}$-R-salt from $\left[\mathrm{Ru}(\mathrm{CN})_{6}\right]^{4-}$, a modified mechanistic scheme has been proposed. MET can be quantitatively determined up to $2.5 \times 10^{-6} \mathrm{M}$ level by the proposed analytical method. The methodology can be economically and effectively employed for the quantitative estimation of MET in distinct samples.
\end{abstract}

Keywords: methionine; hexacyanoruthenate(II); inhibitory effect; nitroso-R-salt; Michaelis constant; catalyst inhibitor complex.

(C) 2020 by the authors. This article is an open-access article distributed under the terms and conditions of the Creative Commons Attribution (CC BY) license (https://creativecommons.org/licenses/by/4.0/).

\section{Introduction}

Methionine, one of the nine essential amino acids in humans, plays an important role in growth and tissue repair. It is the only sulfur-containing essential amino acid and acts as a precursor for the other amino acids, such as taurine and cysteine, antioxidant glutathione, and SAM-e [1,2]. Methionine strengthens nails and boosts the pliability and tone of hair as well as skin. Sulfur provided by methionine slows cell aging, is involved in many detoxifying processes, essential for bioavailability and absorption of zinc and selenium, and protects cells from pollutants [3]. Methionine aids the excretion of heavy toxic metals like mercury and leads through the chelation process [4]. Methionine is used for the prevention of liver damage in the case of acetaminophen poisoning [5]. It is also used for improving wound healing, treating liver disorders, increasing the acidity of urine, diaper rash in infants, and also helps to control strong urine odor [6,7]. Other uses include treating asthma, radiation side effects, depression, Parkinson's disease, allergies, schizophrenia, copper poisoning, drug withdrawal, and alcoholism [8,9]. Methionine is found in high amounts in egg white, sesame seeds, fishes (mahi-mahi, halibut, and salmon), chicken, dairy products, and many vegetables, including asparagus, mushrooms, zucchini, and spinach [10]. The senile greying of hair is also linked with methionine loss resulting in hydrogen peroxide buildup in hair follicles leading to a 
reduction in tyrosinase effectiveness and a gradual loss of hair color [11]. Studies on mice show that the low methionine diet increases the lifespan by $40 \%$ as well as slows the rate of aging of mice [12]. The daily-recommended intake of methionine plus cysteine is $19 \mathrm{mg} / \mathrm{kg}$ per day for adults. Methionine is considered the most toxic amino acid in connection to growth in animals, but no serious toxicity is evidenced in the case of humans [13]. Overall, it appears that methionine is not particularly toxic in healthy humans, except at extremely high doses that would be virtually impossible to obtain through the diet.

The kinetic investigation and mechanistic elucidation of catalyzed and uncatalyzed ligand exchange/oxidation reaction of transition metal complexes in an aqueous medium are of fundamental importance [14-17]. The immediate applications of these reactions in analytical and synthetic chemistry attracted many environmentalists and chemists over the last century $[18,19]$. In this connection, numerous kinetic studies of coordinated cyanide from low-spin hexacyanoruthenate(II) with a variety of ligand containing $-\mathrm{N},-\mathrm{S}$, -P, and $-\mathrm{O}$ donor atoms were investigated by several authors [20,21]. Sulfur is an important element in a large number of drugs and bioactive molecules. Sulfur, present in enzymes and structural proteins of a cell, plays a vital role in various metabolic processes [22-25]. Thus to develop an effective methodology to quantitatively determine sulfur-containing drugs and bioactive molecules in distinct samples are of huge importance and also the demand of the pharmaceutical industry.

Numerous literature is available to quantitatively estimate the sulfur-containing compounds in analytical and biological samples and pharmaceutical preparations [26-29]. The estimation methods include spectrophotometry [30,31], NMR-spectrometry [32], potentiometry [33], voltammetry [34], fluorimetry [35], flow injection analysis [36], chromatography [37-39] and colorimetry [26]. High cost for sample analysis, heavy instrumentation, time-consuming process, and high initial capital investment are the primary drawbacks of most of the reported methods. A small number of kinetic records are present using different determination processes [40-44].

Ruthenium complexes with various bioactive molecules shows wide-range applications as DNA binder [45], Antitumor [46], Antileukemic [47], Immunosuppressant [48], Antimetastatic [49], Anticancer [50], Antiamebic [51] and Antifungal [52]. Several reports are available on the metal-catalyzed exchange of cyanide with nitrogen donor heterocyclic ligand from hexacyanoruthenate(II) in an aqueous / surfactant medium [20,21,53]. The catalytic property of mercury (II) on the cyanide substitution with $\mathrm{N}-\mathrm{R}$-salt from $\left[\mathrm{Ru}(\mathrm{CN})_{6}\right]^{4-}$ has been successfully employed for the micro-level estimation of $\mathrm{Hg}$ (II) [54]. The stability of various metal complexes can be explained by the HSAB (hard-soft acid-base) concept. Organo-sulfur compounds form a stable complex with $\mathrm{Hg}^{2+}$, thereby inhibiting its catalytic activity [42-44]. This inhibitory property of organo-sulfur compounds can be employed for its kinetic determination at the micro-level. MET suppresses the $\mathrm{Hg}^{2+}$ catalyzed exchange rate of cyanide with nitroso-R-salt $\left[\mathrm{N}-\mathrm{R}\right.$-salt] from $\left[\mathrm{Ru}(\mathrm{CN})_{6}\right]^{4-}$. This inhibitory property of MET developed our interest in establishing a precise and simple kinetic spectrophotometric method for the micro-level estimation of MET. The current reaction system in hand produces more accurate results for the MET determination as the uncatalyzed reaction between N-R-salt and hexacyanoruthenate(II) is insignificant under the stipulated experimental condition. The current communication dealt with the development of a new and accurate analytical method, which permits the estimation of MET in various samples down to $2.5 \times 10^{-6} \mathrm{M}$ with good reproducibility. 


\section{Materials and Methods}

\subsection{Reagents used.}

In all kinetic measurements, double deionized water and analytical-grade reagents were used. The weighed amount of $\mathrm{K}_{4}\left[\mathrm{Ru}(\mathrm{CN})_{6}\right] .3 \mathrm{H}_{2} \mathrm{O}$ (Sigma-Aldrich) and nitroso-R-salt (Merck) was used to prepare their stock solutions and kept in the dark to prevent their possible photodegradation. Methionine, procured from Hi-media, was used without further purification. To prevent the loss of $\mathrm{Hg}^{2+}$ via adsorption on the glass surface, its dilution was done prior to the kinetic run. $\mathrm{KNO}_{3}$ (CDH Fine Chemicals) was used to regulate the ionic strength $(\mu)$, while the $\mathrm{pH}$ of the reaction medium was managed by $\mathrm{HCl} / \mathrm{NaOH}$ (Sigma-Aldrich) and potassium hydrogen phthalate procured from S D Fine Chemical Limited.

\subsection{Instrumentation and kinetic procedure.}

Mettler Toledo F20 digital pH meter was used to carry out $\mathrm{pH}$ measurements. The $\mathrm{pH}$ meter was calibrated with the predefined buffer solutions. All kinetic measurements were carried out on Lasany double beam microprocessor UV-Visible spectrophotometer model-LI2700 by recording the hike in absorbance at $525 \mathrm{~nm}$, the $\lambda_{\max }$ of stable purple-red-colored $\left[\mathrm{Ru}(\mathrm{CN})_{5} \mathrm{~N}-\mathrm{R}-\mathrm{salt}\right]^{3-}$ complex. No modification in absorbance was applied as only $\left[\mathrm{Fe}(\mathrm{CN})_{5}\right.$ $\mathrm{N}-\mathrm{R}$-salt ${ }^{3-}$ absorbs strongly while the other reactants and catalyst show negligible absorption at this wavelength. The optimized indicator reaction condition exhibiting a significant change in the absorbance values was judiciously selected from the detailed kinetic study [54]. All the reacting solutions viz., $\mathrm{KNO}_{3}=0.05 \mathrm{M},\left[\mathrm{Ru}(\mathrm{CN}) 6^{4}\right]=5.25 \times 10^{-5} \mathrm{M}$, buffer of $\mathrm{pH}=7.0 \pm$ $0.02,[\mathrm{~N}-\mathrm{R}$-salt $]=6.5 \times 10^{-4} \mathrm{M},\left[\mathrm{Hg}^{+2}\right]=5.5 \times 10^{-5} \mathrm{M}$ and methionine were thermally equilibrated for $30 \mathrm{~min}$ at $45^{\circ} \mathrm{C}$ and were mixed swiftly in the sequence: buffer solution, N-Rsalt, $\mathrm{KNO}_{3}, \mathrm{HgCl}_{2}$ and methionine. Hexacyanoruthenate(II) solution was injected lastly to initiate the substitution reaction. The reaction mixture was vigorously shaken and transferred promptly to the spectrophotometric cuvette having a temperature-controlled cell compartment. The progress of the substitution reaction was monitored by observing the hike in absorbance corresponding to the stable purple-red-colored $\left[\mathrm{Ru}(\mathrm{CN})_{5} \mathrm{~N} \text {-R-salt }\right]^{3-}$ complex at $525 \mathrm{~nm}$. A calibration plot drawn between the absorbance measured at $525 \mathrm{~nm}$ and varying [MET] was used for the quantitative estimation of MET.

\section{Results and Discussion}

The $\mathrm{Hg}(\mathrm{II})$ promoted substitution of $\mathrm{CN}^{-}$with $\mathrm{N}-\mathrm{R}$-salt from $\left[\mathrm{Ru}(\mathrm{CN})_{6}\right]^{4-}$ results in a stable purple-red-colored $\left[\mathrm{Ru}(\mathrm{CN})_{5} \mathrm{~N}-\mathrm{R} \text {-salt }\right]^{3-}$ complex. Metal to ligand charge transfer (MLCT) complex is responsible for the strong absorption band for the product at $525 \mathrm{~nm}$. Only $\left[\mathrm{Fe}(\mathrm{CN})_{5} \mathrm{~N}-\mathrm{R} \text {-salt }\right]^{3-}$ absorbs strongly while the other reactants and catalysts show negligible absorption at this wavelength [54]. The previous reports on sodium thiosulphate and thioglycolic acid exhibit that the thio compounds inhibit the substitution rate of cyanide from $\left[\mathrm{Ru}(\mathrm{CN})_{6}\right]^{4-}$ by nitrogen donor incoming ligand catalyzed by $\mathrm{Hg}^{2+}$ [42-44]. The rate of investigated reaction will also decrease by the addition of methionine as it forms a stable catalyst-inhibitor $\left[\mathrm{Hg}^{2+}----\mathrm{MET}\right]$ complex with $\mathrm{Hg}^{2+}$. The formation of this complex reduces the effective concentration of $\mathrm{Hg}^{2+}$, which ultimately results in the loss of its catalytic activity. A proportional decrease in the rate of inhibitor reaction was observed with the inclusion of MET. The change in absorbance $\left(\mathrm{A}_{\mathrm{t}}\right)$ after 12 and 18 min of mixing of reactants with varying 
[MET] was recorded under optimum reaction condition. The graph plotted between $A_{t}$ and [MET] exhibits a linear relationship in the studied concentration range of MET (Figure 1). The plot can be used for the quantitative estimation of MET as a calibration curve. The expressions relating $A_{t}$ and $[\mathrm{MET}]$ can be represented as Eq.1 and 2.

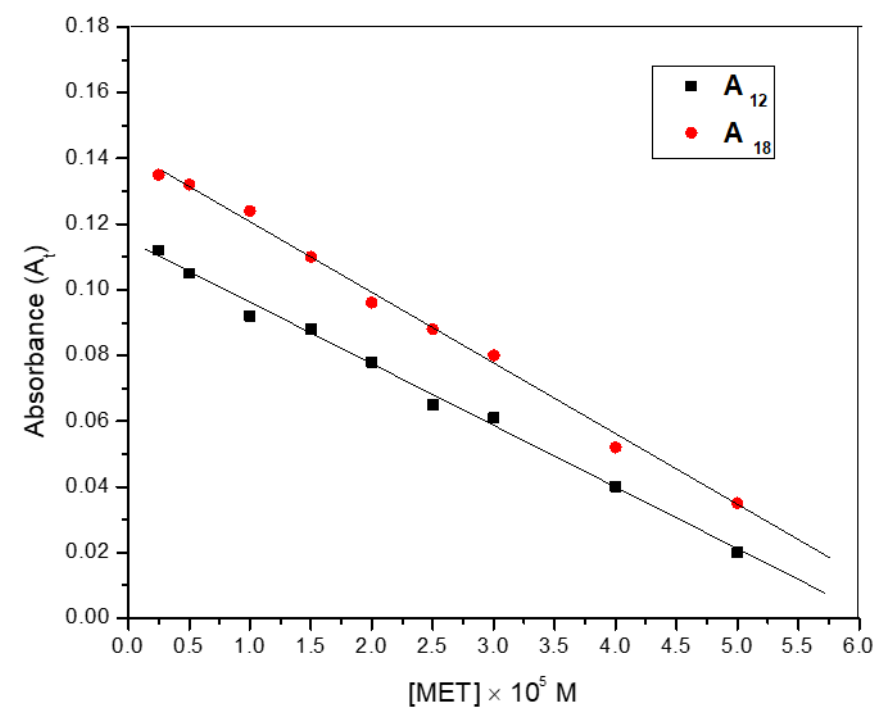

Figure 1. Calibration curve for the Methionine determination. Reaction Condition: $\mathrm{I}=0.05 \mathrm{M}\left(\mathrm{KNO}_{3}\right)$, $[\mathrm{N}-\mathrm{R}-$ salt $]=6.5 \times 10^{-4} \mathrm{M},\left[\mathrm{Hg}^{2+}\right]=5.5 \times 10^{-5} \mathrm{M}, \mathrm{pH}=7.0 \pm 0.02$, Temperature $=45.0 \pm 0.1^{\circ} \mathrm{C}$, and $\left[\mathrm{Ru}(\mathrm{CN})_{6}{ }^{4-}\right]=$ $5.25 \times 10^{-5} \mathrm{M}$

$$
\begin{aligned}
\mathrm{A}_{12} & =0.115-3.72 \times 10^{4}[\mathrm{MET}] \\
\mathrm{A}_{18} & =0.143-4.28 \times 10^{4}[\mathrm{MET}]
\end{aligned}
$$

The graph plotted between $A_{t}$ and [MET] exhibits linear regression coefficient and standard deviation of $0.9971,0.9983$ and $0.0023,0.0007$ for $A_{12}$ and $A_{18}$, respectively. Recovery experiments for MET determination were performed by taking the calculated amount of MET in distilled water to check the accuracy and reproducibility of the current method. Table 1 shows the recovered MET along with standard deviation and percentage error. The MET can be quantitatively determined up to $2.5 \times 10^{-6} \mathrm{M}$ level by the proposed analytical method.

\begin{tabular}{|c|c|c|c|c|}
\hline \multirow[b]{2}{*}{$\begin{array}{l}{[\mathrm{MET}] \times 10^{5} \mathrm{M}} \\
\text { (Taken) }\end{array}$} & \multicolumn{2}{|c|}{$\mathbf{A}_{12}$} & \multicolumn{2}{|c|}{$\mathbf{A}_{18}$} \\
\hline & $\begin{array}{c}{\left[\text { MET] } \times 10^{5} \mathrm{M}\right.} \\
\text { (Found) }\end{array}$ & $\%$ Error & $\begin{array}{c}{\left[\text { MET] } \times 10^{5} \mathrm{M}\right.} \\
\text { (Found) }\end{array}$ & $\%$ Error \\
\hline 0.30 & $0.31 \pm 0.018$ & +0.023 & $0.29 \pm 0.036$ & -0.118 \\
\hline 0.50 & $0.50 \pm 0.02$ & 0.000 & $0.52 \pm 0.00$ & +0.08 \\
\hline 1.25 & $1.21 \pm 0.06$ & -0.048 & $1.25 \pm 0.00$ & 0.000 \\
\hline 1.60 & $1.63 \pm 0.08$ & +0.046 & $1.61 \pm 0.03$ & +0.023 \\
\hline 2.10 & $2.10 \pm 0.00$ & 0.000 & $2.08 \pm 0.07$ & -0.027 \\
\hline 3.25 & $3.22 \pm 0.05$ & -0.052 & $3.28 \pm 0.06$ & +0.059 \\
\hline 4.25 & $4.27 \pm 0.07$ & +0.038 & $4.29 \pm 0.08$ & +0.073 \\
\hline 5.00 & $4.98 \pm 0.025$ & -0.042 & $5.05 \pm 0.05$ & +0.061 \\
\hline
\end{tabular}

Table 1. Recovery results and \% error for MET determination.

Reaction Condition: $\left[\mathrm{Ru}(\mathrm{CN})_{6}{ }^{4}\right]=5.25 \times 10^{-5} \mathrm{M},[\mathrm{N}-\mathrm{R}$-salt $]=6.5 \times 10^{-4} \mathrm{M}, \mathrm{pH}=7.0 \pm 0.02, \mathrm{I}=0.05 \mathrm{M}\left(\mathrm{KNO}_{3}\right),\left[\mathrm{Hg}^{2+}\right]=5.5 \times 10^{-5} \mathrm{M}$ and Temperature $=45.0 \pm 0.1^{\circ} \mathrm{C}$.

To better explain the inhibitory effect of sulfur donor ligand, methionine on $\mathrm{Hg}^{2+}$ catalyzed exchange of cyanide with N-R-salt from $\left[\mathrm{Ru}(\mathrm{CN})_{6}\right]^{4-}$; a modified mechanistic scheme has been proposed by equations (3) - (7).

The current reaction system in hand produces more accurate results for the MET determination as the uncatalyzed reaction between N-R-salt and hexacyanoruthenate(II) is 
insignificant under the stipulated experimental condition (not presented in the proposed scheme) [54].

$$
\begin{aligned}
& {\left[\mathrm{Ru}(\mathrm{CN})_{6}\right]^{4-}+\quad \mathrm{Hg}^{2+}+\mathrm{H}_{2} \mathrm{O} \stackrel{\mathrm{K}}{\rightleftharpoons}\left[(\mathrm{CN})_{5} \mathrm{RuCN}-------\left(\mathrm{Hg}^{2+}\right)------\mathrm{H}_{2} \mathrm{O}\right]^{2-}} \\
& \begin{array}{r||l}
\text { - Inhibitor (I) } & + \text { Inhibitor (I) } \\
\mathrm{K}_{\mathrm{Cl}}^{\prime} & \mathrm{K}_{\mathrm{Cl}}
\end{array} \\
& \mathrm{Hgl} \\
& \text { (Catalyst Inhibitor complex) }
\end{aligned}
$$

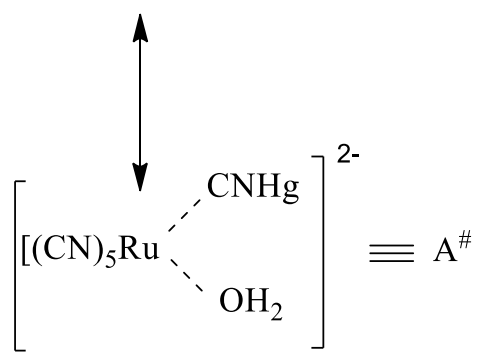

$$
\begin{aligned}
& -\mathrm{HgCN}^{+} \mid \mathrm{k}_{1} \text { (slow) } \\
& {\left[\mathrm{Ru}(\mathrm{CN})_{5} \mathrm{H}_{2} \mathrm{O}\right]^{3-}} \\
& \begin{array}{l|l}
-\mathrm{H}_{2} \mathrm{O} & +\mathrm{N}-\mathrm{R} \text {-salt } \\
\text { fast } & \mathrm{k}_{2}
\end{array} \\
& {\left[\mathrm{Ru}(\mathrm{CN})_{5}-\mathrm{N}-\mathrm{R}-\mathrm{salt}\right]^{3-}} \\
& \mathrm{HgCN}^{+}+\mathrm{H}^{+} \rightleftharpoons \mathrm{Hg}^{2+}+\mathrm{HCN}
\end{aligned}
$$

The rate expression in the presence of an inhibitor can be represented in a similar manner as that for the enzyme-catalyzed reaction for a single substrate. In the defection of inhibitor, the catalyzed reaction rate is given by Eq. (8).

$$
\mathrm{V}_{\mathrm{o}}=\frac{\mathrm{V}_{\max }}{1+\frac{\mathrm{K}_{\mathrm{m}}}{\left[\mathrm{S}_{\mathrm{o}}\right]}}
$$

Where $S_{o}$ represents the initial concentration of substrate, $\left[\mathrm{Ru}(\mathrm{CN}) 6^{4-}\right]$.

Eq. (8) can be transformed to Lineweaver-Burk expression [55] (Eq. 9).

$$
\frac{1}{\mathrm{~V}_{\mathrm{o}}}=\frac{1}{\mathrm{~V}_{\max }}+\frac{\mathrm{K}_{\mathrm{m}}}{\mathrm{V}_{\max }} \frac{1}{\left[\mathrm{~S}_{\mathrm{o}}\right]}
$$

Here $\mathrm{V}_{\max }$ corresponds to the maximum rate at a larger substrate concentration. $\mathrm{K}_{\mathrm{m}}$ and $\mathrm{V}_{\mathrm{o}}$ represent the M-M (Michaelis-Menten) constant and the initial rate of catalyzed reaction, respectively, in the presence of catalyst only.

The graph plotted between $1 / \mathrm{V}_{\mathrm{o}}$, and $1 /\left[\mathrm{S}_{\mathrm{o}}\right]$ is in accordance with the straight-line equation (Figure 2). The value of $\mathrm{K}_{\mathrm{m}}$ for the $\mathrm{Hg}^{2+}$ catalyzed reaction in the absence of an inhibitor can be computed using the intercept and slope of the plot and was found to be 0.124 $\pm 0.014 \mathrm{mM}$.

In the presence of inhibitor (MET), at constant catalyst concentration, the rate of indicator reaction $\left(\mathrm{V}_{\mathrm{i}}\right)$ can be governed by equation (10).

$$
\begin{aligned}
& \mathrm{K}_{\mathrm{m}}^{\prime}=\mathrm{K}_{\mathrm{m}}\left(1+\frac{\left[\mathrm{I}_{\mathrm{o}}\right]}{\mathrm{K}_{\mathrm{CI}}^{\prime}}\right) \\
\mathrm{V}_{\mathrm{i}}= & \frac{\mathrm{V}_{\mathrm{max}}}{1+\frac{\mathrm{K}_{\mathrm{m}}^{\prime}}{\left[\mathrm{S}_{\mathrm{o}}\right]}}
\end{aligned}
$$


Where $\mathrm{K}^{\prime} \mathrm{CI}$ represents the dissociation constant of the catalyst inhibitor complex (C-I), $\mathrm{K}_{\mathrm{m}}^{\prime}$ shows apparent M-M constant in the presence of inhibitor at fixed $\left[\mathrm{Hg}^{2+}\right]$, and the initial concentration of inhibitor (MET) is represented by $\mathrm{I}_{\mathrm{o}}$ [56].

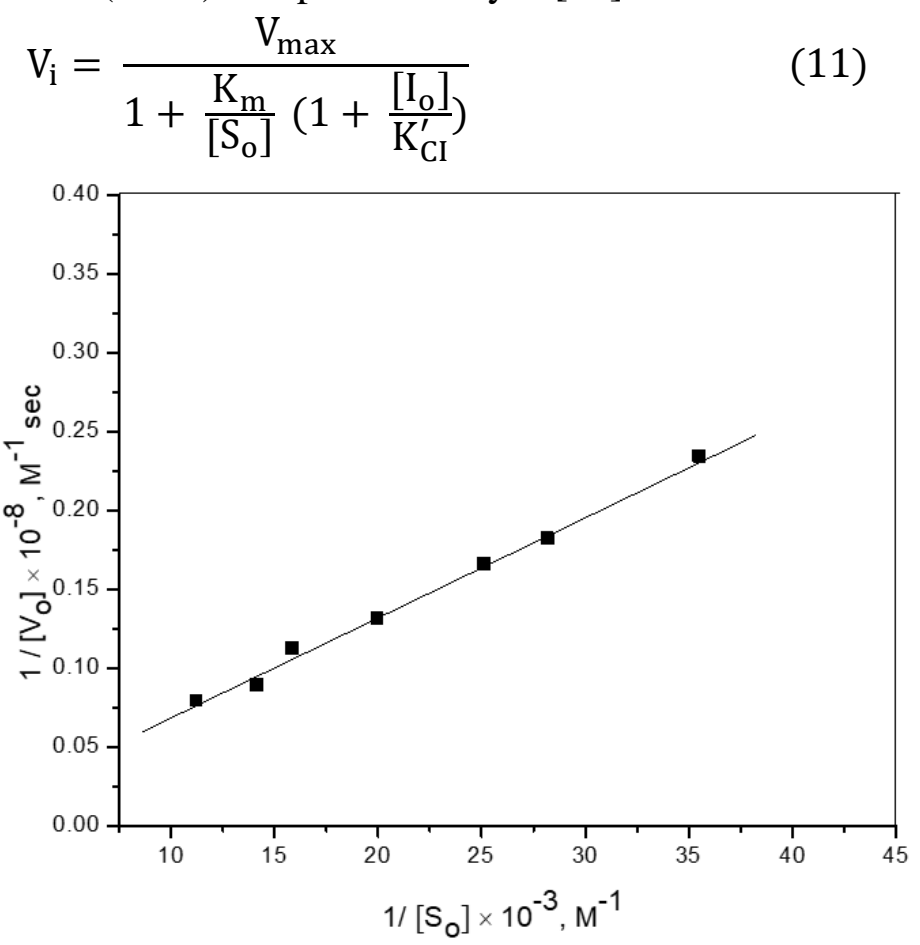

Figure 2. The Lineweaver-Burk plot in the absence of inhibitor at constant $\left[\mathrm{Hg}^{+2}\right]$. Reaction Condition: $\mathrm{I}=0.05$ $\mathrm{M}\left(\mathrm{KNO}_{3}\right)$, Temperature $=45.0 \pm 0.1^{\circ} \mathrm{C},[\mathrm{N}-\mathrm{R}$-salt $]=6.5 \times 10^{-4} \mathrm{M},\left[\mathrm{Hg}^{2+}\right]=5.5 \times 10^{-5} \mathrm{M}$ and $\mathrm{pH}=7.0 \pm 0.02$

Equation (11) can be represented similarly as Lineweaver-Burk expression

$$
\frac{1}{\mathrm{~V}_{\mathrm{i}}}-\frac{1}{\mathrm{~V}_{\max }}=\frac{\mathrm{K}_{\mathrm{m}}}{\left[\mathrm{S}_{\mathrm{o}}\right] \mathrm{V}_{\max }}+\frac{\mathrm{K}_{\mathrm{m}}}{\left[\mathrm{S}_{\mathrm{o}}\right] \mathrm{V}_{\max }} \frac{\left[\mathrm{I}_{\mathrm{o}}\right]}{\mathrm{K}_{\mathrm{CI}}^{\prime}}
$$

To validate and obtain good results from equations (12), the inhibitor should not form a complex with the substrate during the course of the inhibitor reaction while it must form a stable complex with catalyst "C".

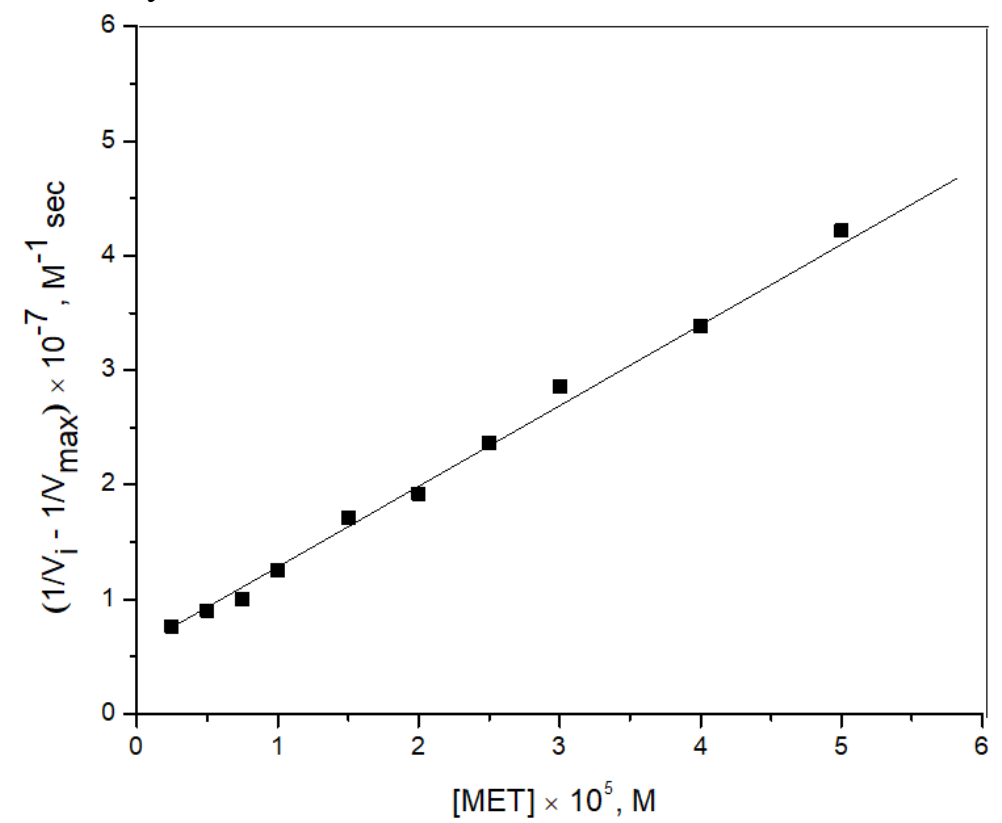

Figure 3. The plot of $\left(1 / \mathrm{V}_{\mathrm{i}}-1 / \mathrm{V}_{\max }\right)$ versus initial [MET]. Reaction Condition: $\mathrm{I}=0.05 \mathrm{M}\left(\mathrm{KNO}_{3}\right)$, Temperature $=45.0 \pm 0.1{ }^{\circ} \mathrm{C},[\mathrm{N}-\mathrm{R}$-salt $]=6.5 \times 10^{-4} \mathrm{M},\left[\mathrm{Hg}^{2+}\right]=5.5 \times 10^{-5} \mathrm{M}, \mathrm{pH}=7.0 \pm 0.02$, and $\left[\mathrm{Ru}(\mathrm{CN})_{6}^{4-}\right]$ $=5.25 \times 10^{-5} \mathrm{M}$. 
The graph plotted between $\left(\frac{1}{V_{i}}-\frac{1}{V_{\max }}\right)$ and initial [MET] is in accordance with the straight-line equation (Figure 3). The intercept of the plot was used to compute the value of $\mathrm{K}_{\mathrm{m}}$ in the presence of an inhibitor. The value of $K_{m}$ in both the cases, i.e., in the presence or absence of inhibitor, is approximately the same $(0.124 \pm 0.014 \mathrm{mM})$. From the slope of the plot, the calculated value of $\mathrm{K}^{\prime} \mathrm{Cr}$ analogs to the $\mathrm{Hg}$-(MET) complex was $6.86 \times 10^{-6} \pm 0.02$. The lower value of the dissociation constant indicates the formation of a stable $\mathrm{Hg}$-(MET) complex.

The A12 calibration curve was used to check the possible interference caused by the various chelating ligands, cations, and anions for the quantitative estimation of MET. The maximum limit of various ions and poly amino carbonates are reported in table 2 . To get accurate results in the determination of MET, the poly-dentate ligands having the ability to form a stable complex with $\mathrm{Hg}$ (II) must not be present during the kinetic investigation as they can interfere significantly in methionine determination. Furthermore, no metal ions and anions, which can interfere with the detection of MET should be present.

Table 2. Effect of diverse ions on Methionine (MET) determination.

Reaction Condition: $\mathrm{I}=0.05 \mathrm{M}\left(\mathrm{KNO}_{3}\right)$, Temperature $=45.0 \pm 0.1^{\circ} \mathrm{C},[\mathrm{N}-\mathrm{R}$-salt $]=6.5 \times 10^{-4} \mathrm{M},\left[\mathrm{Hg}^{2+}\right]=5.5 \times 10^{-}$ ${ }^{5} \mathrm{M}, \mathrm{pH}=7.0 \pm 0.02$, and $\left[\mathrm{Ru}(\mathrm{CN})_{6}{ }^{4-}\right]=5.25 \times 10^{-5} \mathrm{M}$

\begin{tabular}{l|l|l} 
Foreign ion & {$[$ Foreign ion $] \mathbf{M}$, limit } & Interference \\
\hline $\mathrm{Na}^{+}$ & $6.5 \times 10^{-5}$ & Non interfering \\
\hline $\mathrm{Mg}^{2+}$ & $5.5 \times 10^{-4}$ & Non interfering \\
\hline $\mathrm{Cd}^{2+}$ & $7.5 \times 10^{-5}$ & Non interfering \\
\hline $\mathrm{Zn}^{2+}$ & $3.5 \times 10^{-4}$ & Non interfering \\
\hline $\mathrm{Fe}^{3+}$ & $7.5 \times 10^{-4}$ & Non interfering \\
\hline $\mathrm{Al}^{3+}$ & $4.5 \times 10^{-4}$ & Non interfering \\
\hline $\mathrm{I}^{-}$ & $6.0 \times 10^{-4}$ & Non interfering \\
\hline $\mathrm{NO}_{3}{ }^{-}$ & $2.5 \times 10^{-4}$ & Almost noninterfering \\
\hline $\mathrm{C}_{2} \mathrm{O}_{4}^{2-}$ & $3.5 \times 10^{-4}$ & Interfering significantly \\
\hline $\mathrm{SO}{ }^{2-}$ & $2.5 \times 10^{-4}$ & Almost noninterfering \\
\hline IDA & $5.5 \times 10^{-4}$ & Interfering significantly \\
\hline EDTA & $7.5 \times 10^{-4}$ & Interfering significantly
\end{tabular}

\section{Conclusions}

Using the inhibitory effect of sulfur compounds towards $\mathrm{Hg}(\mathrm{II})$, a new, rapid, and accurate kinetic spectrophotometric method was developed for the quantitative determination of MET. The current reaction system in hand produces more accurate results for the MET determination as the uncatalyzed reaction between N-R-salt and hexacyanoruthenate(II) is insignificant under the stipulated experimental condition. The inclusion of methionine only reduces the rate of substitution reaction. The absence of interfering metal ions and organic moieties increases the accuracy of the result. The MET can be quantitatively determined up to $2.5 \times 10^{-6} \mathrm{M}$ level by the proposed analytical method. The methodology can be economically and effectively employed for the quantitative estimation of MET in distinct samples.

\section{Funding}

This research received no external funding.

\section{Acknowledgments}

This research has no acknowledgment. 


\section{Conflicts of Interest}

The authors declare no conflict of interest.

\section{References}

1. Brosnan, J.T.; Brosnan, M.E. The sulfur-containing amino acids: An overview. J Nutr 2006, 136, 16361640, https://doi.org/10.1093/jn/136.6.1636S.

2. Stipanuk, M.H.; Ueki, I. Dealing with methionine/homocysteine sulfur: cysteine metabolism to taurine and inorganic sulfur. J Inherit Metab Dis 2011, 34, 17-32, https://doi.org/10.1007/s10545-009-9006-9.

3. Fairweather-Tait, S.J.; Collings, R.; Hurst, R. Selenium bioavailability: current knowledge and future research requirements. Am J Clin Nutr 2010, 91, 1484-1491, https://doi.org/10.3945/ajen.2010.28674J.

4. Jan A.T.; Azam, M.; Siddiqui, K.; Ali, A.; Choi, I.; Haq, Q.M. Heavy metals and human health: mechanistic insight into toxicity and counter defense system of antioxidants. Int J Mol Sci 2015, 16, 29592-29630, https://doi.org/10.3390/ijms161226183.

5. Guo, T.; Chang, L.; Xiao, Y.; Liu, Q. S-adenosyl-L-methionine for the treatment of chronic liver disease: a systematic review and meta-analysis. PLoS One 2015, 10, https://doi.org/10.1371/journal.pone.0122124.

6. Rocha, K.; Kip, P.; MacArthur, M.R. Preoperative protein or methionine restriction preserves wound healing and reduces hyperglycemia. J Surg Res 2019, 235, 216-222, https://doi.org/10.1016/j.jss.2018.09.071.

7. Siener, R.; Struwe, F.; Hesse, A. Effect of L-methionine on the risk of phosphate stone formation. Urology 2016, 98, 39-43, https://doi.org/10.1016/j.urology.2016.08.007.

8. Hinz, M.; Stein, A.; Cole, T.; McDougall, B.; Westaway, M. Parkinson's disease managing reversible neurodegeneration. Neuropsychiatr Dis Treat 2016, 12, 763-775, https://doi.org/10.2147/NDT.S98367.

9. Strain, J.J.; Lynch, S.M. Excess dietary methionine decreases indices of copper status in the rat. Ann Nutr Metab 1990, 34, 93-97, https://doi.org/10.1159/000177574.

10. Finkelstein, J.D. Methionine metabolism in mammals. $J$ Nutr Biochem 1990, 1, 228-237, https://doi.org/10.1016/0955-2863(90)90070-2.

11. Yale, K.; Juhasz, M.; Atanaskova M.N. Medication-induced regimentation of gray hair: A systematic review. Skin Appendage Disord 2020, 6, 1-10, https://doi.org/10.1159/000504414.

12. Richie, J.P.; Jr, Leutzinger, Y.; Parthasarathy, S.; Malloy, V.; Orentreich, N.; Zimmerman, J.A. Methionine restriction increases blood glutathione and longevity in F344 rats. FASEB Journal 1994, 8, 1302-1307, https://doi.org/10.1096/fasebj.8.15.8001743.

13. Garlick, P.J. Toxicity of methionine in humans. $J$ Nutr 2006, 136, 1722-1725, https://doi.org/10.1093/jn/136.6.1722S.

14. Omondi, R.O.; Stephen, O.; Ojwach, S.O.; Jaganyi, D. Review of comparative studies of cytotoxic activities of $\mathrm{Pt}(\mathrm{II}), \mathrm{Pd}(\mathrm{II}), \mathrm{Ru}(\mathrm{II}) /(\mathrm{III})$ and $\mathrm{Au}(\mathrm{III})$ complexes, their kinetics of ligand substitution reactions and DNA/BSA interactions. Inorg Chim Acta 2020, 512, https://doi.org/10.1016/j.ica.2020.119883.

15. Naik, R.M.; Srivastava, A.; Asthana, A. The kinetics and mechanism of oxidation of hexacyanoferrate(II) by periodate ion in highly alkaline aqueous medium. J Iran Chem Soc 2008, 5, 29-36, https://doi.org/10.1007/BF03245812.

16. Iioka, T.; Takahashi. S.; Yoshida, Y.; Matsumura, Y.; Hiraoka, S.; Sato, H. A kinetics study of ligand substitution reaction on dinuclear platinum complexes: Stochastic versus deterministic approach. J Comput Chem 2019, 40, 279-285, https://doi.org/10.1002/jcc.25588.

17. Naik, R.M.; Srivastava, A.; Verma, A.K.; Yadav, S.B.S.; Singh, R.; Prasad, S. The kinetics and mechanism of oxidation of triethylenetetraaminehexaacetate. Bioinorg Reac Mech 2007, 6, 185-192, https://doi.org/10.1515/IRM.2007.6.3.185.

18. Srivastava, A.; Sharma, V.; Prajapati, A.; Srivastava, N.; Naik, R.M. Spectrophotometric determination of ruthenium utilizing its catalytic activity on oxidation of hexacyano ferrate(II) by periodate ion in water samples. Chem Chem Technol 2019, 13, 275-279, https://doi.org/10.23939/chcht13.03.275.

19. Prasad, S.; Naik, R.M.; Srivastava, A. Application of ruthenium (III) catalyzed oxidation of Tris(2-amino ethyl) amine in trace determination of ruthenium in environmental water samples. Spectrochim Acta A $\mathbf{2 0 0 8}$ 70, 958-65, https://doi.org/10.1016/j.saa.2007.10.011

20. Rastogi, R.; Srivastava, A.; Naik, R.M. Kinetic and mechanistic analysis of ligand substitution of aquapentacyanoruthenate(II) in micelle medium by nitrogen donor heterocyclic ligand. J Disp Sc Tech 2020, 41, 1045-1050. https://doi.org/10.1080/01932691.2019.1614042.

21. Srivastava, A.; Naik, R.M.; Rastogi, R. Spectrophotometric kinetic study of mercury(II) catalyzed formation of $\left[4-\mathrm{CN}-\mathrm{PyRu}(\mathrm{CN})_{5}\right]^{3-}$ via ligand exchange reaction of hexacyanoruthenate(II) with 4-cyanopyridine - a mechanistic approach. J Iran Chem Soc 2020, 17, 2327-2333, https://doi.org/10.1007/s13738-020-01927-w.

22. Tang, K. Chemical diversity and biochemical transformation of biogenic organic sulfur in the ocean. Front Mar Sci 2020, 7, https://doi.org/10.3389/fmars.2020.00068.

23. Abadie, C.; Tcherkez, G. Plant sulphur metabolism is stimulated by photorespiration. Communications Biology 2019, 2, https://doi.org/10.1038/s42003-019-0616-y. 
24. Kolluru, G.K.; Shen, X.; Kevil, C.G. Reactive sulfur species: a new redox player in cardiovascular pathophysiology. Arterioscler Thromb Vasc Biol 2020, 40, 874-884, https://doi.org/10.1161/ATVBAHA.120.314084.

25. Fukuto, J.M.; Ignarro, L.J.; Nagy, P.; Wink, D.A.; Kevil, C.G.; Feelisch, M.; Cortese-Krott, M.M.; Bianco, C.L.; Kumagai, Y.; Hobbs, A.J.; Lin, J.; Ida, T.; Akaike, T. Biological hydropersulfides and related polysulfides-a new concept and perspective in redox biology. FEBS Lett. 2018, 592, 2140-2152, https://doi.org/10.1002/1873-3468.13090.

26. Huang, Y.; Lin, T.; Hou, L.; Ye, F.; Zhao, S. Colorimetric detection of thioglycolic acid based on the enhanced $\mathrm{Fe}^{3+}$ ions Fenton reaction. Microchem J 2019, 144, 190-194, https://doi.org/10.1016/j.microc.2018.09.003.

27. Dedov, A.G.; Marchenko, D.Y.; Zrelova, L.V.; Ivanova, E.A.; Sandzhieva, D.A.; Parkhomenko, A.A.; Budinov, S.V.; Lobakova, E.S.; Dol'nikova, G.A. New Method for Determination of Total of Organic Sulfur Compounds in Hydrocarbon Media. Petroleum Chemistry 2018, 58, 714-720, https://doi.org/10.1134/S0965544118080030.

28. Kostara, A.; Tsogas, G.Z.; Vlessidis, A.G.; Giokas, D.L. Generic assay of sulfur-containing compounds based on kinetics inhibition of gold nanoparticle photochemical growth. ACS Omega 2018, 3, 16831-16838, https://doi.org/10.1021/acsomega.8b02804.

29. Raab, A.; Feldmann, J. Biological sulphur-containing compounds - Analytical challenges. Anal Chim Acta 2019, 1079, 20-29, https://doi.org/10.1016/j.aca.2019.05.064.

30. Zhang, S.; Jiang, J.Q. Detection of imidacloprid and Bisphenol-S by Solid Phase Extraction (SPE) coupled with UV-VIS spectrometer and LC-MS. Biointerface Res Appl Chem 2019, 9, 4433-4438, https://doi.org/10.33263/BRIAC95.433438.

31. Ni, L.; Geng, X.; Li, S.; Ning, H.; Guan, Y. A flame photometric detector with a silicon photodiode assembly for sulfur detection. Talanta 2020, 207, https://doi.org/10.1016/j.talanta.2019.120283.

32. Nelson, J. Nuclear magnetic resonance spectroscopic method for determination of penicillamine in capsules. J Assoc Off Anal Chem 1981, 64, 1174-1178, https://doi.org/10.1093/jaoac/64.5.1174.

33. Chao, Q.; Sheng, H.; Cheng, X.; Ren, T. Determination of sulfur compounds in hydrotreated transformer base oil by potentiometric titration. Ana Sci 2005, 21, 721-724, https://doi.org/10.2116/ANALSCI.21.721.

34. Shoba, S.; Bankole, O.M.; Ogunlaja, A.S. Electrochemical determination of trace sulfur containing compounds in model fuel based on a silver/polyaniline-modified electrode. Anal Methods 2020, 12, 10941106, https://doi.org/10.1039/C9AY02382H.

35. Nugrahani, I.; Abotbina, I.M.; Apsari, C.N.; Kartavinata, T.G.; Sukranso.; Oktaviary, R. Spectrofluorometric determination of L-tryptophan in canary (Canarium indicum L.) seed protein hydrolysate. Biointerface Res Appl Chem 2019, 10, 4780-4785, https://doi.org/10.33263/BRIAC101.780785.

36. Perez-Ruiz, T.; Martinez- Lozano, C.; Tomas, V.; Sidrach-de-cardona, C. Flow-injection fluorimetric determination of penicillamine and tiopronin in pharmaceutical preparations. J Pharm Biomed Anal 1996, 15, 33-38, https://doi.org/10.1016/0731-7085(96)01821-3.

37. Feng, G.; Sun, S.; Wang, M.; Zhao, Q.; Liu, L.; Hashi, Y.; Jia, R. Determination of four volatile organic sulfur compounds by automated headspace technique coupled with gas chromatography-mass spectrometry. J Water Supply Res T 2018, 67, 498-505, https://doi.org/10.2166/aqua.2018.011.

38. Dzieko, U.; Kubczak, N.; Przybylska, K.P.; Patalski, P.; Balcerek, M. Development of the method for determination of volatile sulfur compounds (vscs) in fruit brandy with the use of HS-SPME/GC-MS. Molecules 2020, 25, https://doi.org/10.3390/molecules25051232.

39. Cao, L.; Wei, T.; Shi, Y.; Tan, X.; Meng, J. Determination of D-penicillamine and tiopronin in human urine and serum by HPLC-FLD and CE-LIF with 1,3,5,7-tetramethyl-8-bromomethyl-difluoroboradiaza-sindacene. J Liq Chrom Relat Tech 2018, 41, 58-65, https://doi.org/10.1080/10826076.2017.1348953.

40. Prasad, S. Kinetic determination of organosulphur ligands by inhibition: Trace determination of cysteine and $\begin{array}{lllll}\text { maleonitriledithiolate } \quad \text { Microchem } & J & \mathbf{2 0 0 7}, & 85,\end{array}$ https://doi.org/10.1016/j.microc.2006.05.011.

41. Naik, R.M.; Prasad, S.; Kumar, B.; Yadav, S.B.; Asthana, A.; Yoshida, M. Ligand substitution kinetic assay of antitubercular drug isoniazid in pure and pharmaceuticals formulations. Microchem J 2013, 111, 108-115. https://doi.org/10.1016/j.microc.2013.02.011.

42. Skowron, M.; Ciesielski, W. Spectrophotometric determination of methimazole, Dpenicillamine, captopril, and disulfiram in pure form and drug formulations. $J$ Anal Chem 2011, 66, 714-719, https://doi.org/10.1134/S1061934811080132.

43. Srivastava, A. Micro-level estimation of Mercaptoacetic acid using its inhibitory effect to mercury catalyzed ligand exchange reaction of hexacyanoruthenate(II). Biointerface Res Appl Chem 2020, 10, 7152-7161, https://doi.org/10.33263/BRIAC106.71527161.

44. Agarwal, A.; Prasad, S.; Naik, R.M. Inhibitory kinetic spectrophotometric method for the quantitative estimation of D-penicillamine at micro levels. Microchem $J$ 2016, 128, 181-186, https://doi.org/10.1016/j.microc.2016.04.005. 
45. Yu, B.; Rees, T.W.; Liang, J.; Jin, C.; Chen, Y.; Ji, L.; Chao, H. DNA interaction of ruthenium(II) complexes with imidazo $[4,5-f][1,10]$ phenanthroline derivatives. Dalton Trans 2019, 48, 3914-21, https://doi.org/10.1039/C9DT00454H.

46. Lin, K.; Zhao, Z.Z.; Bo, H.B.; Hao, X.J.; Wang, J.Q. Applications of ruthenium complex in tumor diagnosis and therapy. Pharmacol 2018, 9, https://doi.org/10.3389/fphar.2018.01323.

47. Kenny, R.G.; Marmion, C.J. Toward multi-targeted platinum and ruthenium drugs-A new paradigm in cancer drug treatment regimens? Chem Rev 2019, 119, 1058-1137, https://doi.org/10.1021/acs.chemrev.8b00271.

48. Bastos, C.M.; Gordon, K.A.; Ocain, T.D. Synthesis and immunosuppressive activity of ruthenium complexes. Bioorg Med Chem Lett 1998, 8, 147-150, https://doi.org/10.1016/s0960-894x(97)10205-0.

49. Gua, L.; Lia, X.; Ran, Q.; Kang, C.; Lee, C.; Shen, J. Antimetastatic activity of novel ruthenium (III) pyridine complexes. Cancer Med 2016, 5, 2850-2860, https://doi.org/10.1002/cam4.826.

50. Coverdale, J.P.C.; Carron, T.L.M.; Canelon, I.R. Designing ruthenium anticancer drugs: what have we learnt from the key drug candidates? Inorganics 2019, 7, https://doi.org/10.3390/inorganics7030031.

51. Athar, F.; Husain, K.; Abid, M.; Azam, A. Synthesis and anti-amoebic activity of gold(I), ruthenium(II), and copper(II) complexes of metronidazole. Chem Biodiversity 2005, 2, 1320-1330, htpps://dio.org/10.1002/cbdv.200590104

52. Gomes-Junior, F.A.; Silva, R.S.; Lima, R.G.; Vannier-Santos, M.A. Antifungal mechanism of

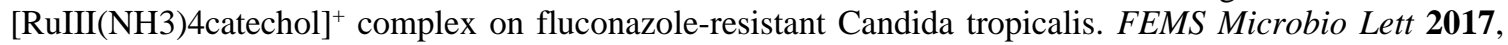
364, https://doi.org/10.1093/femsle/fnx073.

53. Naik, R.M.; Singh, P.K.; Rastogi, R.; Singh, R.; Agarwal, A. Kinetic-catalytic and spectrophotometric determination of $\mathrm{Hg}$ (II) using its catalytic effect on ligand substitution reaction between hexacyanoferrate(II) and pyrazine. Annali di Chimica 2007, 97, 1169-1179, https://doi.org/10.1002/adic.200790103.

54. Naik, R.M.; Agarwal, A.; Verma, A.K.; Yadav, S.B.S.; Kumar, B. Kinetics of the mercury(II)-catalyzed substitution of coordinated cyanide ion in hexacyanoruthenate(II) by nitroso-R-salt. Int J Chem Kinet 2009, 41, 215-226, https://doi.org/10.1002/kin.20391

55. Lineweaver, H.; Burk, D. The determination of enzyme dissociation constants. J Am Chem Soc 1934, 156, 658-666, https://doi.org/10.1021/ja01318a036.

56. Tinoco, I.; Sauer, K.; Wang, J.C. Physical chemistry, Principles and applications in biological sciences. Prentice-Hall Inc., New Jersey, USA, 1978; pp. 351. 